\title{
Identifikasi Stomata Pteridophyta di Kawasan Air Terjun Parangkikis Pagerwojo Tulungagung Jawa Timur
}

\author{
Arbaul Fauziah ${ }^{1 *}$ \\ ${ }^{1)}$ Tadris Biologi UIN Sayyid Ali Rahmatullah Tulungagung, Indonesia \\ ${ }^{*}$ Koresponden Penulis : arbaulfauziah@gmail.com
}

\begin{abstract}
ABSTRAK
Stomata merupakan salah satu karakter tumbuhan yang sering digunakan oleh ahli taksonomi dalam sistem klasifikasi untuk mengidentifiksai spesies tumbuhan. Penelitian ini bertujuan untuk mengidentifikasi karakter morfologi stomata Pteridophyta di kawasan Air Terjun Parangkikis Pagerwojo, Tulungagung. Tahap pertama pada pengamatan stomata adalah pembuatan preparat bagian abaksial daun. Preparat ini dibuat dengan metode replika. Karakter stomata yang diteliti meliputi jenis dan ukuran stomata, jumlah sel stomata dan epidermis, serta nilai indeks stomata. Hasil penelitian menunjukkan jenis stomata Pteridophyta adalah polositik dan anomositik. Dari 15 spesies Pteridophyta yang diamati, tipe stomatanya adalah polositik, kecuali Selaginella yang memiliki stomata bertipe anomositik. Bentuk stomata lonjong terdapat pada Selaginella intermedia dan Phymatosorus sp., agak lonjong (ginjal) terdapat pada Asplenium apogamum, Dryopteris sp., Asplenium normale, Nephrolepis bisserata, Nephrolepis davallioides, Asplenium nidus, dan Pteris longipinnula, bulat terdapat pada Cyathea sp., Dicranopteris linearis, Cyclosorus arida, Goniophlebium percussom, dan Goniophlebium manmiense, dan bentuk tidak cekung terdapat pada Coniogramme fraxinea. Ukuran stomata berpengaruh terhadap jumlah stomata. Semakin kecil ukuran stomata maka jumlah stomata semakin banyak. Jumlah stomata terbanyak terdapat pada $D$. linearis yaitu 362 buah, sedangkan jumlah stomata paling sedikit terdapat pada pada $S$. intermedia yaitu 18 buah. Data jumlah stomata dan sel epidermis digunakan untuk menentukan indeks stomata. Indeks stomata tertinggi terdapat pada D. linearis yaitu sebesar $22.05 \%$ dan terendah terdapat pada C. fraxinea, yaitu $5.44 \%$.
\end{abstract}

Kata kunci: anomositik, Parangkikis, polositik, Pteridophyta, stomata

\begin{abstract}
Stomata is one of the plant characters used by taxonomists in the classification system to identify plant species. The aim of this study was to identifiy the stomata morphological characters of Pteridophyta in the Parangkikis Pagerwojo Waterfall area, Tulungagung. The first step of stomata observation was preparation of the abaxial leaf slice. The preparation was carried out by the replica method. Stomata character studied include types and size of stomata, the number of stomata and epidermis cells, and value of the stomatal index. The result of this study showed that stomata types of Pteridophyta were polocytic and anomocytic. Of the 15 Pteridophyta species observed, the all of stomata type were polocytic, except Selaginella which had type stomata anomocytic. Stomata oval was found in Selaginella intermedia and Phymatosorus sp., slightly oval (kidney) was found in Asplenium apogamum, Dryopteris sp., Asplenium normale, Nephrolepis bisserata, Nephrolepis davallioides, Asplenium nidus, and Pteris longipinnula sp., spherical was found in Dicranopteris linearis, Cyclosorus arida, Goniophlebium percussom, and Goniophlebium manmiense, and nonconcave was found in Coniogramme fraxinea. Stomata size affected the number of stomata. If the size of the stomata was small, the number of stomata was increasing. The highest number of stomata was found in D. linearis, which was 362, while the least number of stomata was S. intermedia, which was 18. Data on the number of stomata and epidermal cells were used to determine the stomatal index. The highest stomata index was found in D. linearis, which was $22.05 \%$ and the lowest was C. fraxinea, which was $5.44 \%$.
\end{abstract}

Keywords: Anomocytic, Parangkikis, polocytic, Pteridophyta, stomata 


\section{Pendahuluan}

Tipe stomata merupakan salah satu kajian yang dibutuhkan oleh ahli taksonomi untuk mengidentifiksai spesies tumbuhan dan mengetahui hubungan kekerabatan antar spesies [1]. Penggunaan stomata untuk keperluan tersebut salah satunya terdapat pada tumbuhan paku (pteridophyta). [2] melaporkan bahwa karakteristik stomata dapat digunakan untuk membedakan jenis tumbuhan paku pada marga Pteris. Perbedaan jenis tumbuhan paku dapat diketahui berdasarkan ciri kuantitatif anatomi paradermal daun, meliputi rata-rata ukuran stomata, epidermis, amplitudo, dan panjang lekukan sel epidermis serta kerapatan dan indeks stomata.

Epidermis merupakan lapisan terluar dari sel baik pada permukaan daun, bunga, buah, biji, batang, dan akar [3]. Epidermis memiliki struktur yang bervariasi. Setiap tumbuhan memiliki stuktur sel epidermis yang berbeda, meliputi bentuk, ukuran, susunan, jumlah, dan kedudukan sel epidermis terhadap stomata, jarak antar stomata, serta jarak antara epidermis dengan stomata. Stomata merupakan epidermis yang berkembang dan mengalami modifikasi. Stomata biasanya terdapat pada bagian tumbuhan yang berhubungan dengan udara, seperti daun, batang, dan rizoma. Namun, pada umumnya stomata banyak ditemukan pada daun terutama pada permukaan bawah daun (abaksial) [4]. Tata letak stomata yang bervariasi di antara beberapa spesies merupakan salah satu mekanisme adaptasi tumbuhan dalam kaitannya dengan transpirasi. [5] menyatakan bahwa stomata berperan sebagai struktur dasar yang berfungsi untuk mengurangi kehilangan air dari daun. Stomata dengan ukuran lebar akan lebih lambat dalam merespon dehidrasi, sehingga stomata dapat dijadikan sebagai salah satu faktor penentu efisiensi penggunaan air pada tumbuhan.

Tumbuhan paku dapat hidup di berbagai habitat, seperti hutan primer, hutan sekunder, alam terbuka, dataran tinggi maupun rendah, lingkungan basah, lembab, rindang, kebun, bahkan hingga tepi jalan raya [6]. Salah satu lingkungan lembab dan rindang yang kaya akan jenis tumbuhan paku adalah Air Terjun Parangkikis. Sebagai daerah yang berada di lereng pegunungan, Air Terjun Parangkisis tergolong kawasan yang asri, masih sangat rindang, dan kealamiannya masih terjaga karena belum ada pengolahan dari pihat terkait. [7] melaporkan tingginya keanekaragam tumbuhan paku di Kawasan Air Terjun Parangkisis Pagerwojo. Pada kawasan tersebut ditemukan 20 jenis tumbuhan paku yang terdiri dari 2 kelas, 9 famili, dan 13 genus.

Meskipun di Kawasan Air Terjun Parangkisis Pagerwojo telah banyak ditemukan berbagai jenis Pteridopyta, namun identifikasi stomata Pteridophyta pada kawasan ini belum pernah dilaporkan. Sehingga kajian tentang tipe dan morfologi stomata serta struktur sel epidermis pada Pteridopyta masih terbatas pada wilayah tertentu. Hasil penelitian [8] di Gua Cerme Bantul menunjukkan bahwa terdapat variasi tipe stomata pada beberapa tumbuhan paku. Tumbuhan Adiantum induratum Chirt, J. Bot. (Morot), Adiantum capillus-veneris Linn, Adiantum philippense Linn., Adiantum malesianum J. Ghatak Selaginella sp., dan Selaginella indica (Milde) R. M. Tryon memiliki stomata bertipe anomositik. Sedangkan Pyrrosia petiolosa (Christ) Ching memiliki tipe stomata anisositik dan Pneumatopteris sp. memiliki tipe stomata diasitik.

Berdasarkan hal tersebut, maka penelitian ini dilakukan untuk menggali informasi lebih dalam mengenai tipe, bentuk, ukuran, dan jumlah stomata serta struktur sel epidermis pada Pteridophyta di Kawasan Air Terjun Parangkisis Pagerwojo. Pemilihan Kawasan Air Terjun Parangkisis Pagerwojo sebagai lokasi penelitian disebabkan kawasan ini termasuk area wisata yang kondisinya masih alami. Dengan demikian, melalui penelitian ini diharapkan akan diperoleh informasi mengenai stomata Pteridophyta yang tumbuh alami di habitatnya dan belum terpengaruh oleh cekaman alam seperti pencemaran lingkungan, degradasi, polusi, atau cekaman lainnya. 


\section{Metode}

\section{Pengambilan Sampel}

Sampel spesies Pteridophyta diambil dari Kawasan Air Terjun Parangkikis. Sampel yang diambil berupa daun paku dewasa. Hal ini disebabkan daun paku dewasa lebih mudah digunakan untuk bahan pembuatan preparat. Sedangkan bentuk daun paku muda adalah menggulung [9] sehingga sulit dibuat preparat dengan metode replika. Sampel yang diambil kemudian dimasukkan ke dalam kantong plastik agar daun tidak rusak dan layu. Sampel dalam kantong plasik dibawa ke laboratorium IPA UIN Sayyid Ali Rahmatullah Tulungagung.

\section{Pengamatan Stomata}

Pengamatan stomata diawali dengan pembuatan preparat stomata. Pembuatan preparat stomata dilakukan dengan metode replika [10]. Sampel dikeluarkan dari kantong plastik dan dibersikan permukaan daunnya. Permukaan daun yang sudah bersih diolesi dengan kutek bening dan dibiarkan hingga kuteknya kering. Bagian permukaan daun yang diolesi kutek tersebut ditutup dengan selotip bening. Selotip yang telah merekat pada permukaan daun kemudian dilepas secara perlahan-lahan sehingga epidermis abaksialnya menempel pada selotip. Selotip yang sudah tertempel dengan epidermis abaksial daun direkatkan pada objek glass dan diamati dengan mikroskop binokuler CX 31 Olympus pada perbesaran $400 \mathrm{x}$. Pengamatan yang dilakukan meliputi tipe, ukuran, dan bentuk stomata, jumlah stomata dan sel epidermis, serta indeks stomata.

\section{Penghitungan Indeks Stomata}

Indeks stomata dihitung menggunakan rumus [11] yaitu dengan menyatakan jumlah stomata per satuan luas sebagai persentase dari jumlah total atau sel epidermis.

Indeks Stomata $(I)=\frac{S}{S+E}$

$\mathrm{I}=$ Indeks stomata

$\mathrm{S}=$ Jumlah stomata per satuan luas

$\mathrm{E}=\mathrm{Jumlah}$ sel epidermis per satuan luas

\section{Hasil dan Diskusi}

Tipe stomata pada 15 jenis Pteridophyta yang berada di kawasan Air Terjun Parangkikis adalah polositik dan anomositik. Sebagian besar tipe stomata di antara beberapa spesies tersebut adalah polositik. Tipe stomata polositik dijumpai pada Asplenium apogamum, Asplenium normale, Asplenium nidus, Pteris longipinnula, Dryopteris sp., Dicranopteris linearis, Coniogramme fraxinea, Cyathea sp., Cyclosorus arida, Goniophlebium percussom, Goniophlebium manmiense, Nephrolepis bisserata, Nephrolepis davallioides, dan Phymatosorus sp. Sedangkan tipe stomata anomositik hanya terdapat pada Selaginella intermedia (Tabel 1). 
e-Jurnal Ilmiah BIOSAINTROPIS (BIOSCIENCE-TROPIC)

Volume 7/ No.: 2 / Halaman 34 - 45 / Januari Tahun 2022

ISSN : 2460-9455 (e) - 2338-2805(p)

Tabel 1. Hasil pengamatan tipe stomata daun Pteridophyta di bawah mikroskop dengan perbesaran $400 \mathrm{x}$

\begin{tabular}{|l|l|l|l|l|}
\hline \multicolumn{1}{|c|}{ Spesies } & Habitus & Permukan Daun & Tampilan Stomata & Tipe \\
Stomata
\end{tabular}


e-Jurnal Ilmiah BIOSAINTROPIS (BIOSCIENCE-TROPIC) Volume 7/ No.: 2 / Halaman 34 - 45 / Januari Tahun 2022 ISSN : 2460-9455 (e) - 2338-2805(p)

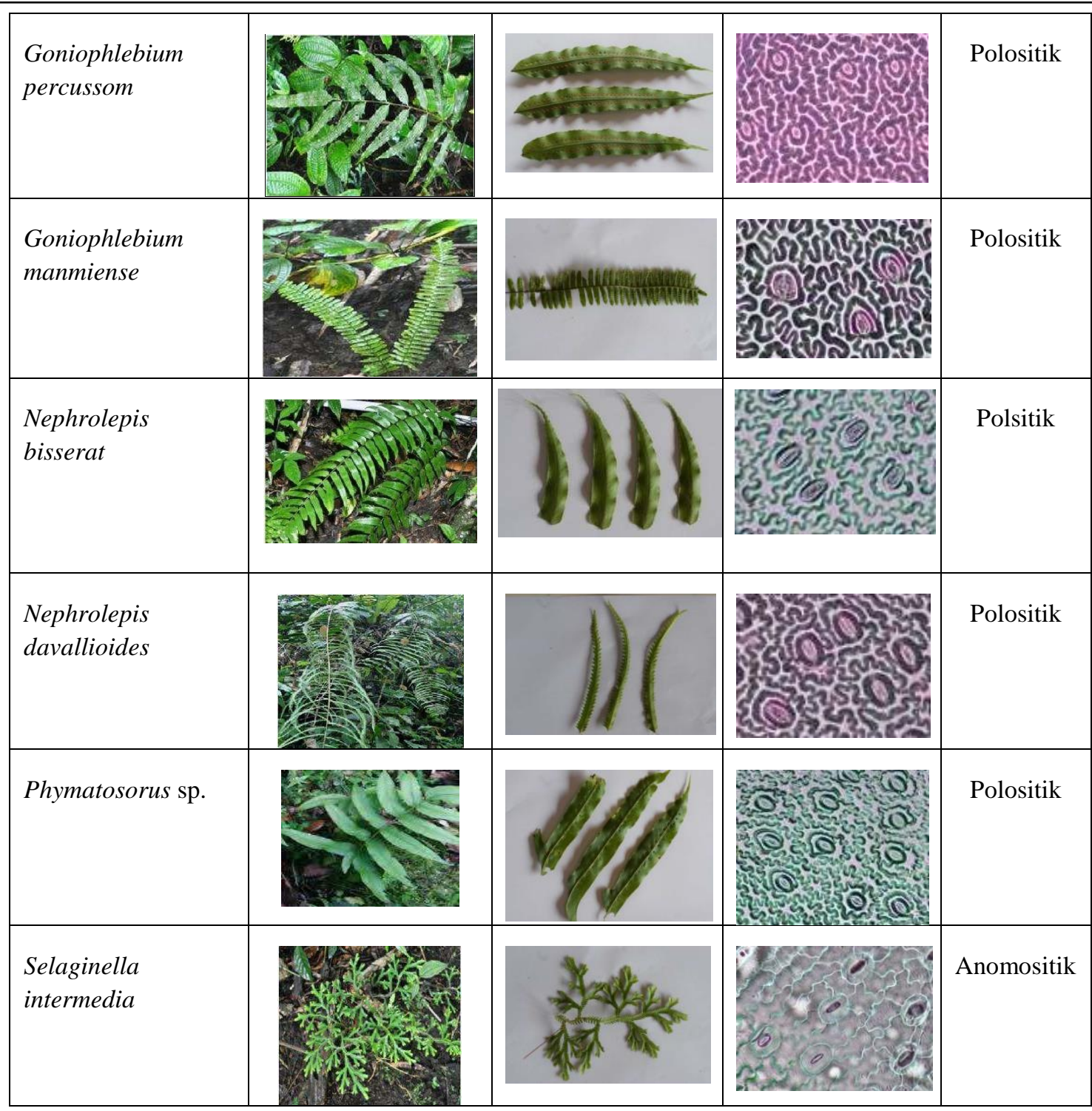

Pada penelitian ini dilaporkan bahwa stomata Asplenium normale bertipe polositik. Menurut [12], tipe stomata beberapa spesies dari genus Asplenium yang tegolong famili Aspleniaceae adalah polositik. Tipe stomata polositik yaitu tipe stomata yang dikelilingi oleh satu sel tetangga dan juga tipe stomata dengan sel tetangga berbentuk $U$ dan mengelilingi hampir seluruh bagian sel penjaga dari ujung distal [13]. [14] juga menyatakan bahwa tipe polositik merupakan tipe stomata yang jaringan mersitem stomatanya membelah secara melengkung untuk membentuk sel tetangga dan sel penjaga. Sel tetangga menjadi berbentuk $U$ dan mengelilingi bagian sel penjaga dari ujung distal. Sedangkan tipe stomata anomositik adalah merupakan tipe stomata dengan komposisi sel penjaga dikelilingi oleh sejumlah sel tetangga yang tidak berbeda dengan sel epidermis di sekitarnya dan bentuk maupun ukuran sel tetanga tersebut sama dengan sel epidermis sekitarnya [15]. Hal ini disebabkan pada tipe anomositik, jaringan meristem stomata membelah menjadi dua sel penjaga. Sehingga pada saat dewasa, sel-sel di sekitarnya atau sel tetangga tidak dapat dibedakan dari sel-sel epidermis lain dalam ukuran dan bentuknya.

Selain itu, tipe stomata pada spesies dari Asplenium lainnya adalah gabungan antara polositik dan anomositik. Sehingga dalam satu spesises yang sama terdapat lebih dari satu macam tipe stomata. Tipe stomata polositik dan anomositik pada Asplenium juga dilaporkan oleh [16]. [17] menyatakan bahwa tipe stomata pada beberapa spesies dari genus Selaginella adalah anomositik dan siklositik. 
e-Jurnal Ilmiah BIOSAINTROPIS (BIOSCIENCE-TROPIC)

Volume 7/ No.: 2 / Halaman 34-45 / Januari Tahun 2022

ISSN : 2460-9455 (e) - 2338-2805(p)

Sedangkan tipe stomata Pteris multifida adalah polositik yang terdiri dari copolositik dan pseudopolositik [18].

Masing- masing stomata yang diidentifikasi pada penelitian ini memiliki bentuk yang berbedabeda, terdiri dari lonjong, agak lonjong, dan bulat. Bentuk stomata lonjong terdapat pada Selaginella intermedia dan Phymatosorus sp. Bentuk stomata lonjong pada Phymatosorus sp. juga dilaporkan oleh [19]. Bentuk stomata agak lonjong terdapat pada Asplenium apogamum, Dryopteris sp., Asplenium normale, Nephrolepis bisserata, Nephrolepis davallioides, Asplenium nidus, dan Pteris longipinnula. [20] juga melaporkan bahwa stomata Nephrolepis bisserata dan Nephrolepis davallioides berbentuk ginjal (agak lonjong), sedangkan stomata berbentuk ginjal pada Asplenium nidus dan Pteris longipinnula telah dilaporkan oleh [21]. Stomata yang berbentuk bulat terdapat pada Cyathea sp. dan Dicranopteris linearis. Selain itu, bentuk stomata bulat juga terdapat pada Cyclosorus arida [22] serta Goniophlebium percussom dan Goniophlebium manmiense [23]. Di samping itu, stomata Pteridophyta juga ada yang bentuknya tidak cekung, yaitu pada Coniogramme fraxinea [24].

Berdasarkan pengamatan yang dilakukan, rata-rata ukuran stomata pada tumbuhan paku sekitar 41.96 - $110.79 \mu \mathrm{m}$. Ukuran stomata terbesar terdapat pada $S$. intermedia sebesar $659.29 \mu \mathrm{m}$, sedangkan ukuran stomata terkecil terdapat pada D. linearis yaitu $20.93 \mu \mathrm{m}$ (Gambar 1).

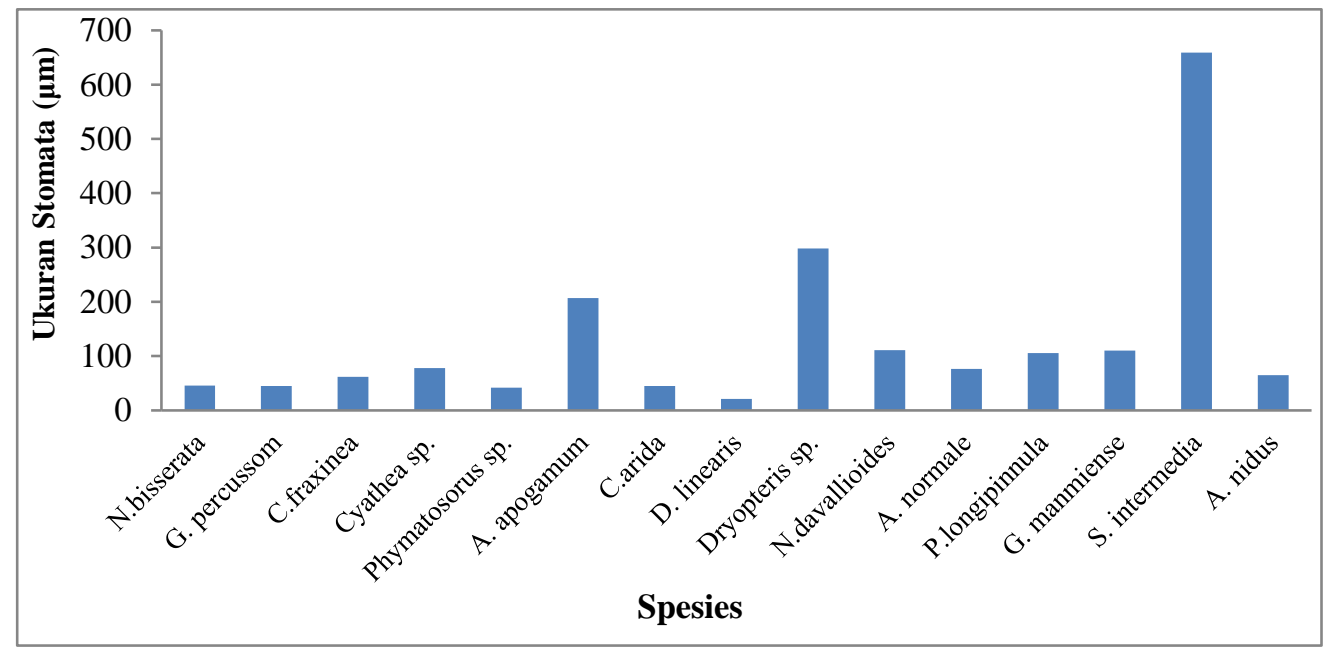

Gambar 1. Ukuran stomata pada permukaan abaksial daun Pteridophyta

Ukuran stomata pada tiap-tiap spesies berkaitan dengan jumlah stomata yang terlihat dalam satu bidang pandang. Semakin kecil ukuran stomata maka jumlah stomata dalam satu bidang pandang semakin banyak. Sebaliknya, semakin besar ukuran stomata maka jumlah stomata dalam satu bidang pandang semakin sedikit. Hal ini sebagaimana yang dilaporkan oleh [25] yang menyatakan bahwa jumlah stomata pada setiap jenis tanaman dapat dipengaruhi oleh ukuran stomata. Apabila ukuran stomata besar maka jumlahnya sedikit, sebaliknya apabila stomata berukuran kecil maka jumlahnya lebih banyak [26]. Jika jumlah stomata banyak, maka tingkat kerapatan stomata akan semakin tinggi. Menurut [27], apabila stomata semakin rapat, maka proses pembukaan dan penutupan stomata akan semakin terhambat. Selain itu, kerapatan stomata juga berpengaruh terhadap jumlah $\mathrm{CO}_{2}$ yang difiksasi oleh tanaman dan $\mathrm{CO}_{2}$ ini merupakan salah satu bahan yang digunakan oleh tanaman untuk proses fotosintetis. Dengan demikian, jumlah serta ukuran (panjang dan lebar) stomata berpengaruh terhadap aktivitas fotosintesis [28].

Masing-masing spesies dari Pteridophyta yang diamati memiliki jumlah stomata yang bervariasi. Jumlah stomata paling banyak terdapat pada $D$. linearis yaitu 362 buah. sedangkan jumlah stomata paling sedikit terdapat pada $S$. intermedia yaitu 18 buah (Gambar 2). 


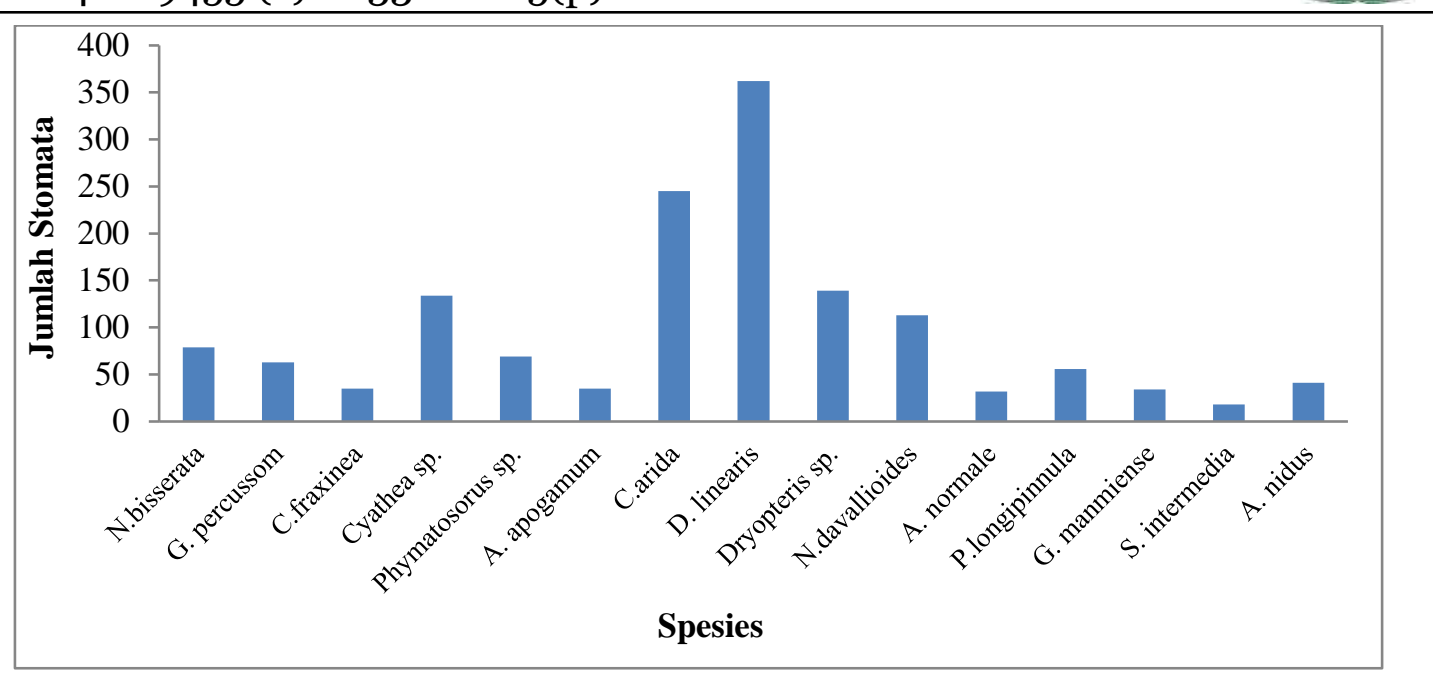

Gambar 2. Jumlah stomata pada permukaan abaksial daun Pteridophyta

Ukuran stomata dapat dipengaruhi oleh tipe daun tumbuhan. [29] menyatakan bahwa pada umumnya daun-daun tanaman ada yang mempunyai helaian menjari atau menyirip dan sejajar atau melengkung. Perbedaan tipe helaian daun ini berpengaruh terhadap dsitribusi stomatanya. Distribusi stomata mengikuti kaidah bentuk daun masing-masing spesies. Pada daun tanaman yang sejajar atau melengkung, daunnya cenderung sempit sehingga ukuran stomatanya relatif lebih kecil dan terlihat lebih rapat dibandingkan dengan tanaman yang daunnya menjari atau menyirip. Pada tumbuhan dengan helaian daun menjari atau menyirip, ukuran stomatanya relatif lebih besar.

[30] menyatakan bahwa faktor yang mempengaruhi perbedaan ukuran stomata terdiri dari faktor internal dan eksternal. Faktor internal ialah sifat genetik. Sedangkan faktor eksternal yaitu lingkungan tempat tumbuhan tersebut yang terdiri dari intensitas cahaya, suhu, udara, tinggi rendahnya kadar polutan, $\mathrm{pH}$ tanah dan ketersediaan air. Variasi ukuran stomata juga dipengaruhi oleh penebalan sel penjaga terhadap respon cahaya, $\mathrm{CO}_{2}$, dan konservasi air. Namun, pada penelitian ini sampel diambil dari lingkungan dengan kondisi yang seragam, baik suhu, $\mathrm{pH}$, ketersediaan air, maupun intensitas cahaya. Sehingga, ukuran stomata hanya dipengaruhi oleh sifat genetik tumbuhan.

Selain berkaitan dengan ukuran stomata, jumlah stomata juga berkaitan dengan indeks stomata. Indeks stomata tertinggi terdapat pada $D$. linearis yaitu sebesar $22.05 \%$ yang mana sedikit lebih tinggi dibandingkan dengan $C$. arida yang memiliki indeks stomata sebesar $21.07 \%$. Sedangkan indeks stomata terendah terdapat pada C. fraxinea, yaitu $5.44 \%$ (Gambar 3).

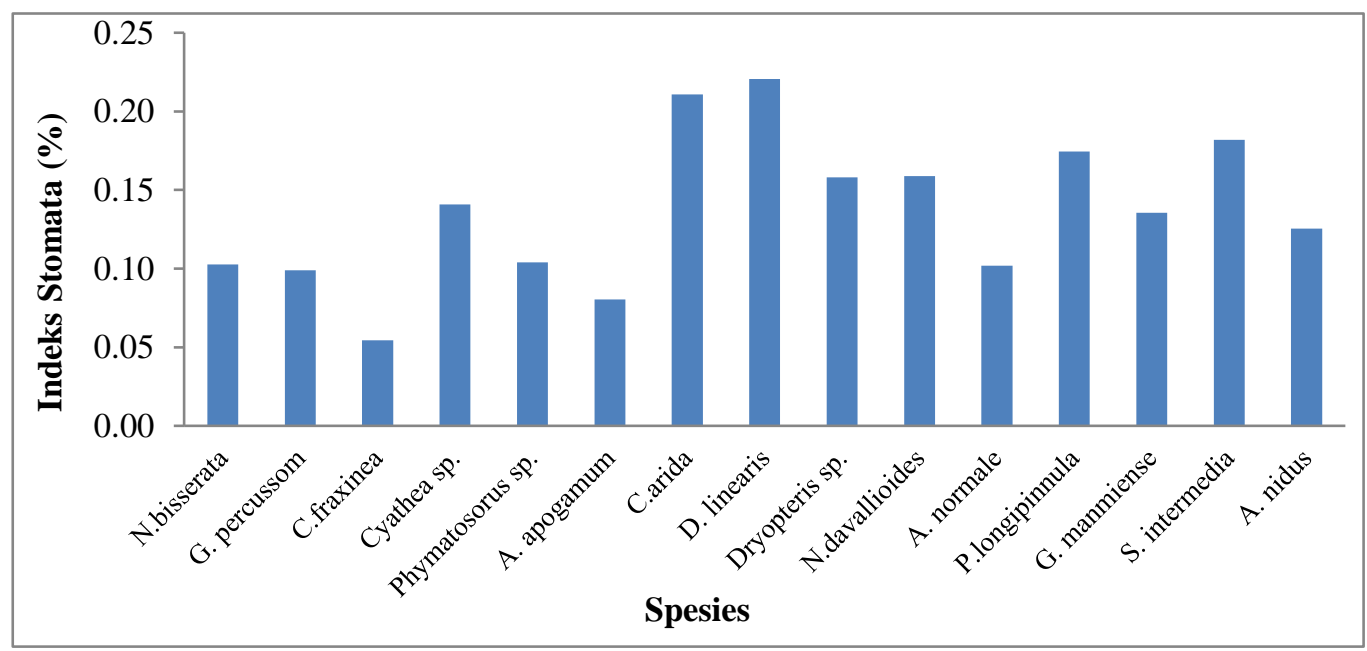

Gambar 3. Indeks stomata pada permukaan abaksial daun Pteridophyta 
Indeks stomata merupakan rasio antara jumlah stomata dengan total jumlah stomata dan sel epidermis. Indeks stomata tidak dipengaruhi oleh jumlah stomata secara mutlak. Hal ini disebabkan terdapat faktor lain yang berpengaruh tehadap indeks stomata, yaitu jumlah sel epidermis. [31] menyatakan bahwa apabila jumlah stomata sedikit dan jumlah epidermisnya banyak, maka indeks stomata akan rendah. Sebaliknya, apabila jumlah stomata banyak dan jumlah epidermisnya sedikit maka indeks stomata akan tinggi.

Jumlah sel epidermis tidak dapat ditentukan berdasarkan ukuran ataupun jumlah stomata. Hal ini disebabkan tiap-tiap spesies memiliki karakteristik sel epidermis yang berbeda, termasuk bentuk, ukuran, dan jarak dengan stomata. Menurut [32], jumlah epidermis dipengaruhi oleh faktor genetik. Di samping itu, fenotipnya juga dipengaruhi oleh faktor lingkungan seperti tinggi rendahnya kadar polutan dan ketersediaan air. Faktor lain yang juga menyebabkan perbedaan jumlah sel epidermis pada masingmasing spesies diungkapkan oleh [33] yang menyebutkan bahwa jumlah daun dan luas daun juga merupakan faktor penentu adanya perbedaan sel epidermis dari masing-masing spesies. Di sisi lain, [34] melaporkan adanya keterkaitan antara ukuran stomata, jumlah stomata, dan jumlah sel epidermis.

Indeks stomata dipengaruhi oleh faktor lingkungan seperti ketersediaan air, intensitas cahaya, temperatur, dan konsentrasi $\mathrm{CO}_{2}$ [35]. [36] mengatakan bahwa perbedaan kerapatan stomata merupakan indikasi respon tanaman terhadap kondisi lingkungan yang ekstrem seperti stress air dan unsur hara dalam mempertahankan fungsi fisiologisnya, misalnya untuk fotosintesis, respirasi, dan transpirsi pada daun. Hal ini menunjukkan bahwa meskipun kerapatan stomata dipengaruhi oleh faktor genetik, fenotipnya sangat dipengaruhi oleh lingkungan. Selain itu, menurut [37], semakin tinggi intensitas cahaya, maka frekuensi stomata di kedua permukaan daun juga semakin meningkat, meskipun peningkatan frekuensi tersebut tidak signifikan. Pada penelitian ini tumbuhan paku diambil dari lingkungan dengan kondisi yang tidak mengalami cekaman/ stress. Bahkan lingkungan ini masih alami dan belum terjamah oleh manusia atau mengalami modifikasi ekosistem, sehingga tidak terdapat faktor eksternal yang berpengaruh terhadap indeks stomata.

Hasil penelitian ini menunjukkan bahwa pada beberapa tumbuhan yang tipe stomatanya sama, bentuk stomata bisa berbeda. Demikian juga ada beberapa tumbuhan yang bentuk stomatanya sama, namun tipe stomatanya berbeda. Asplenium apogamum, Asplenium normale, Asplenium nidus, Nephrolepis bisserata, Nephrolepis davallioides, Dryopteris sp., Pteris longipinnula, Goniophlebium percussom, Goniophlebium manmiense, Cyathea sp., Dicranopteris linearis, dan Cyclosorus arida memiliki tipe stomata yang sama, yaitu polositik. Namun stomata pada Asplenium apogamum, Asplenium normale, Asplenium nidus, Nephrolepis bisserata, Nephrolepis davallioides, Dryopteris sp., Pteris longipinnula berbentuk ginjal (agak lonjong), sedangkan stomata pada Goniophlebium percussom, Goniophlebium manmiense, Cyathea sp., Dicranopteris linearis, dan Cyclosorus arida berbentuk bulat. Jadi, pada penelitian ini diketahui bahwa genus Asplenium dan Nephrolepis memiliki stomata bertipe polositik dan berbentuk ginjal, sedangkan genus Goniophlebium memiliki stomata bertipe polositik dan berbentuk bulat.

\section{Kesimpulan}

Masing- masing spesies Pteridophyta di Kawasan Air Terjun Parangkikis Pagerwojo memiliki tipe, ukuran, jumlah, dan indeks stomata yang bervariasi. Tipe stomata Pteridophyta di kawasan ini terdiri dari polositik dan anomositik. Tipe stomata polositik terdapat pada Asplenium apogamum, Asplenium normale, Asplenium nidus, Pteris longipinnula, Dryopteris sp., Dicranopteris linearis, Coniogramme fraxinea, Cyathea sp., Cyclosorus arida, Goniophlebium percussom, Goniophlebium manmiense, Nephrolepis bisserata Nephrolepis davallioides, dan Phymatosorus sp., sedangkan tipe stomata anomositik terdapat pada Selaginella intermedia. Bentuk stomata terdiri dari lonjong, agak lonjong, dan bulat. Bentuk stomata lonjong terdapat pada Selaginella intermedia dan Phymatosorus sp., agak lonjong (ginjal) terdapat pada Asplenium apogamum, Dryopteris sp., Asplenium normale, Nephrolepis bisserata, Nephrolepis davallioides, Asplenium nidus, dan Pteris longipinnula, bulat terdapat pada Cyathea sp., Dicranopteris linearis, Cyclosorus arida, Goniophlebium percussom, dan 
e-Jurnal Ilmiah BIOSAINTROPIS (BIOSCIENCE-TROPIC)

Volume 7/ No.: 2 / Halaman 34-45 / Januari Tahun 2022

ISSN : 2460-9455 (e) - 2338-2805(p)

Goniophlebium manmiense, serta bentuk tidak cekung terdapat pada Coniogramme fraxinea. Rata-rata ukuran stomata adalah 41.96 - $110.79 \mu \mathrm{m}$. Ukuran stomata terbesar terdapat pada S. intermedia, sedangkan ukuran stomata terkecil terdapat pada D. linearis. Masing-masing spesies dari Pteridophyta memiliki jumlah stomata yang berbeda. Jumlah stomata paling banyak terdapat pada D. linearis, sedangkan jumlah stomata paling sedikit terdapat pada $S$. intermedia. Indeks stomata tertinggi terdapat pada $D$. linearis dan indeks stomata terendah terdapat pada $C$. fraxinea.

\section{Ucapan Terima Kasih}

Penulis mengucapkan terima kasih kepada Fakultas Tarbiyah dan Ilmu Keguruan serta lembaga penelitian dan pengabdian kepada masyarakat UIN Sayyid Ali Rahmatullah Tulungagung sehingga penelitian ini dapat terlaksana. Penulis juga mengucapkan terima kasih kepada Ayu Renita dan Repik Febriansah atas bantuannya dalam analisis stomata di bawah mikroskop.

\section{Daftar Pustaka}

[1] Dasti, A. A.., Bokhari, T. Z., Malik, S. A. and Akhtar, R. 2003. Epidermal Morphology in Some Members of Family Boraginaceae in Baluchistan. Asian Journal of Plant Sciences. 2(1), hal. 42-47. Diterima Tahun 2002. doi:https://dx.doi.org/10.3923/ajps.2003.42.47. URL: https://agris.fao.org/agris-search/search.do?recordID=DJ2012049689.

[2] Astuti, R. E. F., Hadisunarso. and Praptosuwiryo, N. 2019. Anatomi Paradermal Daun Enam Jenis Tumbuhan Paku Marga Pteris. Jurnal LIPI Buletin Kebun Raya. 22(1), hal. 69-84. Diterima $\begin{array}{llll}\text { Tanggal } & 29 & \text { Oktober } & 2018 .\end{array}$ https://publikasikr.lipi.go.id/index.php/buletin/article/view/38.

[3] Nugroho, L. H., Purnomo, and Issirep S. 2010. Struktur dan Perkembangan Tumbuhan. Penebar Swadaya. Jakarta.

[4] Sari, W. D. P. and Herkules. 2017. Analisis Struktur Stomata pada Daun beberapa Tumbuhan Hidrofit sebagai Materi Bahan Ajar Mata Kuliah Anatomi Tumbuhan. Jurnal Biosains. 3(3), hal. 156-161. Diterima Tanggal 3 Desember 2016. doi: https://doi.org/10.24114/jbio.v3i3.8114.URL:https://jurnal.unimed.ac.id/2012/index.php/bi osains/article/view/8114.

[5] Perwati, L. K. 2009. Analisis Derajat Ploidi dan Pengaruhnya terhadap Variasi Ukuran Stomata dan Spora pada Adiantum raddianum. Jurnal BIOMA. 11(2). Hal. 39-44. Diterima Bulan Desember 2009. doi: http://dx.doi.org/10.14710/bioma.11.2.39-44. URL: https://ejournal.undip.ac.id/index.php/bioma/article/view/3360.

[6] Hasanuddin and Mulyadi. 2014. Botani Tumbuhan Rendah. Edisi I. Syiah Kuala University Press. Banda Aceh. Hal. 136.

[7] Renita, A., Eni S., E. Arbaul F., and Nanang P. 2020. Pengembangan Ensiklopedia Tumbuhan Paku Sebagai Sumber Belajar Keanekaragaman Hayat, Jurnal Biologi dan Pembelajarannya. 7(1), hal. 1-6. Diterima Tanggal 22 April 2020. doi: https://doi.org/10.29407/jbp.v7i1.14797.URL:https://ojs.unpkediri.ac.id/index.php/biologi/ article/view/14797/1711.

[8] Salamah, Z., Sasongko H. and Hidayati A. Z. 2020. Inventory of Ferns (Pteridophyta) at Cerme Cave Bantul District. Jurnal Bioscience. 4(1), hal. 97-108. doi: 
e-Jurnal Ilmiah BIOSAINTROPIS (BIOSCIENCE-TROPIC)

Volume 7/ No.: 2 / Halaman 34-45 / Januari Tahun 2022

ISSN : 2460-9455 (e) - 2338-2805(p)

https://doi.org/10.24036/0202041106829-0-00.

URL:

http://ejournal.unp.ac.id/index.php/bioscience/article/view/106829.

[9] Adlini, M.N., Adi H., Miftahul K., Indayana F.B., \& Khairuna. 2021. Identifikasi Tumbuhan Paku (Pteridophyta) di Universitas Islam Negeri (UIN) Sumatera Utara. Biota: Jurnal Ilmiah Ilmu-ilmu Hayati. 6 (2), hal. 87-94. Diterima Bulan Februari 2020. doi: https://doi.org/10.24002/biota.v6i2.3842.

URL: https://ojs.uajy.ac.id/index.php/biota/article/view/3842.

[10] Fauziah, A. \& Annisa S.Z.I. 2019. Analisis Tipe Stomata Pada Daun Tumbuhan Menggunakan Metode Stomatal Printing. Prosiding Seminar Nasional Hayati. 7(1), hal. 34-39. doi: https://doi.org/10.29407/hayati.v7i1.603. Diterima Bulan September 2019. 6 hal. URL: https://proceeding.unpkediri.ac.id/index.php/hayati/article/view/603.

[11] Lestari, E. G. 2006. Hubungan antara Kerapatan Stomata dengan Ketahanan Kekeringan pada Somaklon Padi Gajahmungkur, Towuti, dan IR 64. Journal of Biological Diversity. 7(1), hal. 44-48. Diterima Bulan Januari 2006. doi: https://doi.org/10.13057/biodiv/d070112. URL: https://smujo.id/biodiv/article/view/563.

[12] Mehra, P. N. and Soni, L. N. 1983. Stomatal Patterns in Pteriophytes-An Evolutionary Approach. Journal of the Indian National Science Academy. 49(2): hal. 155-203. Diterima Tanggal 27 Mei 1982. URL: https://agris.fao.org/agris-search/search.do?recordID=US201302206420.

[13] Psenicka, J. and Bek, Jiri. 2003. Cuticles and spores of Senftenbergia plumosa (Artis) Bek and Pšenička from the Carboniferous of Pilsen Basin, Bohemian Massif. Review of Palaeobotany and Palynologi Elseveir Journal. 125(3-4), hal. 299-312. Diterima Tanggal 3 Juli 2002. doi: https://doi.org/10.1016/S0034-6667(03)00006-X. URL: https://www.sciencedirect.com/science/article/abs/pii/S003466670300006X?via\%3Dihub.

[14] Sen, U. and De, B. 1992. Structure and Ontogeny of Stomata in Ferns. Blumea Journal. 37(1), hal. 239-261. Diterima Tahun 1992. URL:https://repository.naturalis.nl/pub/524430.

[15] Meriko, L. and Abizar. 2017. Struktur Stomata Daun beberapa Tumbuhan Kantong Semar (Nepenthes spp.). Jurnal LIPI Berita Biologi. 16(3), hal. 325-330. Diterima Tanggal 18 Juni 2016. doi: https://dx.doi.org/10.14203/beritabiologi.v16i3.2398. URL:https://ejournal.biologi.lipi.go.id/index.php/berita_biologi/article/view/2398.

[16] Chandra, P. 1979. Leaf epidermis in some species of Asplenium L. Journal of the Indian National Science Academy. 88(4), hal. 269-275. Diterima Tanggal 19 Juni 1978. doi: https://doi.org/10.1007/BF03046190.URL:https://link.springer.com/article/10.1007/BF030 $\underline{46190 .}$.

[17] Bautista, M. G. Coriticio, F. P., Acma, F. M. and Amoroso, V. B. 2018. Spikemoss Flora (Selaginella) in Mindanao Island, the Philippines: Species Composition and Phenetic Analysis of Morphological Variations. Philippine Journal of Systematic Biology. 12(1), hal. 45-56. Diterima Tanggal $09 \quad$ April $2018 . \quad$ doi: https://doi.org/10.26757/pjsb.2018a12007.URL:https://www.semanticscholar.org/paper/Sp ikemoss-flora-(-Selaginella-)-in-Mindanao-Island-Bautista Coritico/6444b79be4485fc73eb535b799dee70bb355488d.

[18] Hastuti, D, V., Titin, N. P. and Nina, R.D. 2011. Sitologi dan Tipe Reproduksi Pteris multifida Poir.(Pteridaceae). Jurnal LIPI Buletin Kebun Raya. 14(1), hal. 8-18. Diterima Tanggal 5 Agustus 2010. URL: https://publikasikr.lipi.go.id/index.php/buletin/article/view/124. 
e-Jurnal Ilmiah BIOSAINTROPIS (BIOSCIENCE-TROPIC)

Volume 7/ No.: 2 / Halaman 34-45 / Januari Tahun 2022

ISSN : 2460-9455 (e) - 2338-2805(p)

[19] Shao, Wen., Shu Gang Lu dan Qing Chun Shang. 2011. Comparative Morphology of Leaf Epidermis in The Fern Genus Phymatopteris (Polypodiaceae). Plant Diversity and Resource.33(2), hal.174-182.

[20] Taufiq, I. and Sofiyanti, N. 2020. Karakteristik Stomata dan Epidermis pada Dua Jeis Paku Nephrolepis (Nephrolepidaceae) di Pekanbaru Riau. Journal Online Mahasiswa, hal. 1-7. $\begin{array}{llll}\text { Diterima } & \text { Tanggal Juli } 2919 . & \end{array}$ https://repository.unri.ac.id/xmlui/handle/123456789/10070.

[21] Ariyanto, J. 2014. Taksonomi Polypodiaceae Ditinjau dari Tipe Stomata. Seminar Nasional XI Pendidikan Biologi FKIP UNS. Diterima Bulan Juni 2014. 6 hal. URL: https://www.neliti.com/id/conferences/sembio/2014.

[22] Leon, M. E. M. D., Garcia, B. P., Guzman, J. M. and Ruiz, A. M. 2008. Developmental Gametophyte Morphology of Seven Species of Thelypteris subg. Cyclosorus (Thelypteridaceae). Micron Elsevier Journal. 39(8), hal.1351-1362. Diterima Tanggal 9 November $2007 . \quad$ doi:https://doi.org/10.1016/j.micron.2008.02.001. URL:https://www.sciencedirect.com/science/article/abs/pii/S0968432808000322.

[23] Xu, C. L., Huang, J., Su, T., Zhang, X. C., Li, S. F. and Zhe, K. Z. 2017. The First Megafossil Record of Goniophlebium (Polypodiaceae) from the Middle Miocene of Asia and its Paleoecological Implications. Paleoworld ElsevierJournal. 26(3), hal.543-552. Diterima Tanggal 30 Agustus 2016. doi: https://doi.org/10.1016/j.palwor.2017.01.006. URL: https://www.sciencedirect.com/science/article/abs/pii/S1871174X16300749.

[24] Chuang, Y. and Liu, H. 2003. Leaf Eidermal Morphology and Its Systematic Implications in Taiwan Pteridaceae. Taiwania. 48(1), hal.60-71. Diterima Tanggal 16 Oktober 2002. doi: http://dx.doi.org/10.6165\%2ftai.2003.48(1).60. https://www.researchgate.net/publication/242663712 Leaf Epidermal Morphology and I ts Systematic Implications in Taiwan Pteridaceae.

[25] Tambaru, E., Resti U. and Mustika T. 2018. Karakterisasi Stomata Daun Tanaman Obat Andredera cordifolia (Ten.) Steenis dan Gratophyllum pictum (L.) Griff. Jurnal Ilmu Alam dan Lingkungan. 9(17), hal.42-47.

[26] Saadu, R. O., Abdulrahman. and Oladele, F. A. 2009. Stomatal Complex Types and Transpiration Rates In some Tropical Tuber Species. African Journal of Plant Science. 3(5), hal. 107-112. Diterima Tanggal 28 April 2009. doi: https://doi.org/10.5897/AJPS.9000230. URL: https://academicjournals.org/journal/AJPS/article-abstract/B3A840310802.

[27] Khoiroh, Y., Nunung H., \& Retno M. 2014. Pertumbuhan Serta Hubungan Kerapatan Stomata dan Berat Umbi Pada Amorphophallus muelleri Blume dan Amorphophallus variabilis Blume. Jurnal Biotropika. 2 (5), hal. 249-253. URL: https://biotropika.ub.ac.id/index.php/biotropika/article/view/309.

[28] Palit, J. J. 2008. Teknik Perhitungan Jumlah Stomata pada Beberapa Kultivar Kelapa. Jurnal Buletin Teknik Pertanian. 13(1), hal.1-23. Diterima Bulan September 2008. URL: http://203.190.37.42/publikasi/bt131083.pdf.

[29] Haryanti, S. 2010. Jumlah dan Distribusi Stomata pada Daun Beberapa Spesies Tanaman Dikotil dan Monokotil. Journal Buletin Anatomi dan Fisiologi. 18(2), hal.21-28. Diterima Bulan Oktober 2010. doi: https://doi.org/10.14710/baf.v18i2.2600. URL: https://ejournal.undip.ac.id/index.php/janafis/issue/view/577. 
e-Jurnal Ilmiah BIOSAINTROPIS (BIOSCIENCE-TROPIC)

Volume 7/ No.: 2 / Halaman 34-45 / Januari Tahun 2022

ISSN : 2460-9455 (e) - 2338-2805(p)

[30] Utami, Rati., Entin Daningsih dan Reni Marlina. 2018. Analisis Ukuran dan Tipe Stomata Tanaman di Arboretum Sylva Indonesia PC Untan Pontianak. Jurnal Pendidikan dan Pembelajaran Khatulistiwa. 7(5), hal.1-10. URL: https://jurnal.untan.ac.id/index.php/jpdpb/article/view/25755.

[31] Widianti, P., Violita V., \& Moralita C. 2017. Luas dan Indeks Stomata Daun Tanaman Padi (Oryza Sativa L.) Varietas Cisokan dan Batang Piaman Akibat Cekaman Kekeringan. Bioscience. 1 (2), hal. 77-86. URL: http://ejournal.unp.ac.id/index.php/bioscience/article/view/8082.

[32] Jaya, A. B., Tambaru, E., Latunra, A. I. and Salam, M. A. 2014. Perbandingan Karakteristik Stomata Daun Pohon Leguminosae di Hutan Kota Universitas Hasanuddin dan di Jalan Tamalate Makassar. Jurnal of Biological Doversity. 7 (1), hal.6. URL: https://core.ac.uk/download/pdf/77620772.pdf.

[33] Sundari, T. and Atmaja, R. 2011. Bentuk Sel Epidermis, Tipe dan Indeks Stomata 5 Genotipe Kedelai pada Tingkat Naungan Berbeda. Jurnal Biologi Indonesia. 7(1), hal. 67-79. doi: http://dx.doi.org/10.14203/jbi.v7i1.3129. URL: https://ejournal.biologi.lipi.go.id/index.php/jurnal biologi indonesia/article/view/3129.

[34] Tambaru, E., Latunra, A. I. dan Suhadiyah, S. 2013) Peranan Morfologi dan Tipe Stomata Daun dalam Mengabsorbsi Karbon Dioksida pada Pohon Hutan Kota UNHAS Makassar. Simposium Nasional Kimia Bahan Alam ke XXI, hal.15.

[35] Kimball, J. 2011. Gas Exchange in Plants. Tanggal Akses 18 November 2021. URL: https://www.biology-pages.info/G/GasExchange.html\#leaves.

[36] Juairiah, L. 2014. Studi Karakteristik Stomata Beberapa Jenis Tanaman Revegetasi di Lahan Pasca Penambangan Timah di Bangka. Jurnal Widyariset. 17 (2), hal. 213-218. Diterima Bulan Agustus 2014. doi: http://dx.doi.org/10.14203/widyariset.17.2.2014.213-217. URL: http://www.widyariset.pusbindiklat.lipi.go.id/index.php/widyariset/article/view/26 $\underline{3}$.

[37] Maylani, E. D., Yuniati, R. and Wardhana, W. 2019. The Effect of Leaf Surface Character on the Ability of Water Hyacinth, Eichhornia crassipes (Mart.) Solms. to Transpire Water. IOP Conf. Ser. Mater. Sci. Eng. USA. 29 Mei - 22 Juni 2019. 